\title{
Effect of feeding fat on fibrinolysis, Stypven time, and platelet aggregation in Africans, Asians, and Europeans $^{1}$
}

\author{
J. C. FERGUSON, N. MACKAY, AND G. P. MCNICOL \\ From Makerere University College Medical School Extension, Nairobi, and the University Department \\ of Medicine, Royal Infirmary, Glasgow
}

SYNOPSIS The effects of acute fat feeding on fibrinolytic activity, platelet aggregation, and Stypven time in 10 Africans and 10 Asians are presented and compared with the results previously obtained in 10 Europeans.

These indicated that the inhibition of fibrinolytic activity seen in Europeans does not occur in either Africans or Asians although the Stypven time was shortened in all three groups.

Platelet aggregation, as measured by the Chandler's tube technique, was inhibited by fat feeding in Europeans but was unchanged in Africans and Asians.

The results also indicate that the fibrinolytic activity of Africans and Asians is greater than that of Europeans.

A relationship between thrombogenic mechanisms and atherosclerosis was originally suggested by Rokitansky (1852) and revised by Duguid (1946), who demonstrated that intravascular thrombus may be incorporated into the arterial wall leading eventually to the formation of an atheromatous plaque. On the basis of this hypothesis factors favouring intravascular coagulation might be expected to promote atherosclerosis whereas an increase in blood fibrinolytic activity might be expected to exercise a contrary influence.

A previous investigation (Dubber, Rifkind, Gale, McNicol, and Douglas, 1967) has confirmed that in Europeans acute fat feeding leads to a shortening of the Stypven time and also to inhibition of plasma fibrinolytic activity and platelet aggregation.

This investigation was designed to compare the effects of a high-fat meal on the plasma fibrinolytic activity, blood coagulation, and platelet aggregation in Africans and Asians. The findings have been compared with those already obtained in Europeans. The three ethnic groups had a similar socio-economic status.

Received for publication 2 December 1969.

${ }^{1}$ Ple ase address requests for reprints to: University Department of Materia Medica, Stobhill General Hospital, Glasgow.

\section{Subjects, Materials, and Methods}

The European group previously studied (Dubber et al, 1967) consisted of nine males and one female, aged 26 to 36 years. The two other groups consisted of 10 healthy male Africans, aged 22 to 29 years, and 10 healthy male Asians, aged 22 to 26 years. The Europeans were all members of the hospital staff of the Royal Infirmary, Glasgow, and the Africans and Asians were medical students living in the students' hostel at the Kenyatta National Hospital, Nairobi.

The diet of the African and Asian students was essentially that of the urbanized European, being high in protein and animal fat. Each subject was investigated on two occasions, once after a lowfat breakfast, the control situation, and again after the same breakfast to which had been added $270 \mathrm{~g}$ of double cream. The details of the breakfast are provided in Table I.

Before the breakfast each student had fasted and refrained from smoking from the previous evening. After the breakfast a further three-hour fast was observed and venous blood samples were then taken. Before venepuncture each subject was rested. The order in which the breakfasts were taken was randomized.

After the subject had rested for 15 minutes, and 


\begin{tabular}{lll}
\hline Content & \multicolumn{2}{l}{ Breakfast } \\
\cline { 2 - 3 } & Low Fat & High Fat \\
\hline Carbohydrate (g) & 62.9 & $71 \cdot 0$ \\
Protein (g) & 4.0 & $10 \cdot 2$ \\
Fat (g) & 0.6 & 95.1 \\
\hline
\end{tabular}

Table I Content of both types of breakfast

with minimal occlusion of the circulation, $50 \mathrm{ml}$ of venous blood was obtained in plastic syringes after a clean venepuncture using a needle of gauge no. 19. The blood was allocated as follows: $27 \mathrm{ml}$ in 9-ml amounts was mixed in three chilled siliconized centrifuge tubes, each containing $1 \mathrm{ml}$ of $3.8 \%$ sodium citrate for fibrinolytic, coagulation, and platelet aggregation studies; $2.5 \mathrm{ml}$ was mixed in a sequestrene container (Stayne Laboratories Limited, High Wycombe) for platelet counts; the remainder was collected as serum for lipid assays.

The citrated silicone specimens were kept in ice and centrifuged 10 minutes after collection $\left(600 \mathrm{~g}\right.$ for five minutes at $4^{\circ} \mathrm{C}$ ) to obtain plateletrich plasma.

\section{Methods Used to Assess the Fibrinolytic System}

EUGLOBULIN CLOT LYSIS TIME

This was measured by the method of Nilsson and Olow (1962). Since fibrinolytic activity is proportional to the reciprocal of the lysis time (Sherry and Alkjaersig, 1957), the results were expressed as units of activity, the reciprocal of a lysis time of 300 minutes being taken as 1 unit (Sherry, Lindemeyer, Fletcher, and Alkjaersig, 1959). This test was designed to measure plasma plasminogen activator level.

\section{UROK INASE SENSITIVITY TEST}

This was performed according to the method of McNicol, Gale, and Douglas (1963); $0.32 \mathrm{ml}$ of urokinase (500 Ploug units per $\mathrm{ml}$ ) (Leo Laboratories, Copenhagen) was added to $0.2 \mathrm{ml}$ of plasma which was clotted with $0 \cdot 1 \mathrm{ml}$ thrombin (20 NIH units per $\mathrm{ml}$ ) and the lysis time measured. The results are expressed in units, a unit being defined as the reciprocal of a lysis time of 10 minutes. Urokinase sensitivity in a population is a measure of variations in the levels of fibrinolytic inhibitors.

PLASMINOGEN ASSAY

This was performed by a modification of the caseinolytic method of Remmert and Cohen (1949) as described by Alkjaersig, Fletcher, and Sherry (1959).

\section{FIBRINOGEN ASSAY}

This was performed by a modification of the method of Ratnoff and Menzie (1951) as de scribed by McNicol and Douglas (1964).

\section{PLATELET AGGREGATION}

This was measured by a Chandler's tube tech? nique, modified to use platelet-rich plasma rathe than whole blood. In the European study th\& method was to add $5 \mathrm{ml}$ platelet-rich plasma to $\$$ Chandler's tube (gauge N/17, Portland Plastics, Kent) and make this up to $15 \mathrm{ml}$ with $0.9 \% \mathrm{NaCl}$ The platelet-rich plasma was recalcified with one $\overrightarrow{\vec{L}}$ tenth volume $0.25 \mathrm{M} \mathrm{CaCl}$ exactly 30 minutes after venepuncture and the tube was then places on a turntable of a blood cell suspension mixturis rotating at $25 \mathrm{rpm}$. The time between recalcification and the appearance of the 'snowstorm' effect was taken as the time for platelet aggregation. 0

In the studies on the Africans and the Asians? the basic technique was the same but the volumeswere smaller and the tubing used was narrowe? (gauge $\mathrm{N} / 13$, Portland Plastics, Kent). One $\mathrm{ml}$ of platelet-rich plasma was diluted with $2.5 \mathrm{ml}$ o\% $0.9 \% \mathrm{NaCl}$ and recalcified with $1 \mathrm{ml} 0.25 \mathrm{ML}$ $\mathrm{CaCl}_{2}$.

\section{PLATELET COUNT}

This was performed by the method of Dacie (1956).

STYPVEN (RUSSELL'S VIPER VENOM) TIME This was measured by a modification of the method of MacLagan, Billimoria, and Curtis (1958). The plasma used was that collected in siliconized tubes and centrifuged at $600 \mathrm{~g}$ foi five minutes at $4^{\circ} \mathrm{C}$. It was further centrifuged a $2,000 \mathrm{~g}$ for 15 minutes at $4^{\circ} \mathrm{C}$ to render it plateleb poor. To $0.1 \mathrm{ml}$ of this plasma in a glass test tube at $37^{\circ} \mathrm{C}$, were added simultaneously $0.1 \mathrm{mp}$ Stypven (Burroughs Wellcome \& Co.) and $0.1 \mathrm{mb}$ $0.025 \mathrm{M} \mathrm{CaCl}$, and the clotting time was recorded.

\section{BLOOD LIPID ASSAYS}

Triglyceride levels were measured by the method of Van Handel and Zilversmit (1957).

\section{Results}

EUGLOBULIN CLOT LYSIS TIME

The results are shown in Figure 1. In the Euro? peans the mean euglobulin lysis activity after the high-fat ( 1.10 units) breakfast is significantly les? than the mean activity after a low-fat (1.72 units) breakfast $(t=3.57, P<0.01)$. This difference? 


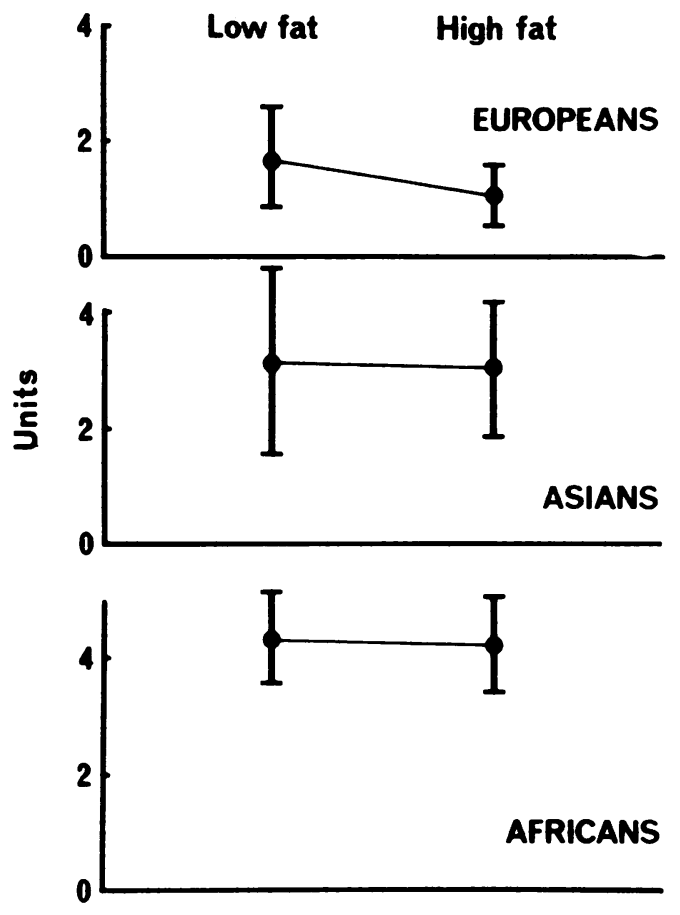

Fig. 1 Euglobulin clot lysis time expressed as units of activity (mean and standard deviation) after both types of breakfast in each group.

was not seen in the Africans $(t=0.52, P>0.70)$ or in the Asians $(t=0.42, P>0 \cdot 1)$.

\section{UROKINASE SENSITIVITY TEST}

These results are shown in Figure 2. In the European group, a reduction in lytic activity was observed after the fat-supplemented breakfast $(\mathrm{t}=3.09, \mathrm{P}<0.02)$. This was not the case in the Africans $(t=0.26, P>0.1)$ or in the Asians $(\mathrm{t}=1 \cdot 23, \mathrm{P}>0 \cdot 1)$.

\begin{tabular}{|c|c|c|c|c|}
\hline & & \multicolumn{2}{|l|}{ Breakfast } & \multirow[t]{2}{*}{ Significance } \\
\hline & & Low Fat & High Fat & \\
\hline $\begin{array}{l}\text { Plasminogen } \\
\text { (casein units) }\end{array}$ & $\begin{array}{l}\text { Europeans } \\
\text { Asians } \\
\text { Africans }\end{array}$ & $\begin{array}{l}2.4 \pm 0.3 \\
2 \cdot 7 \pm 0.4 \\
3 \cdot 2 \pm 0.6\end{array}$ & $\begin{array}{l}2 \cdot 3 \pm 0.2 \\
2 \cdot 8 \pm 0.5 \\
3 \cdot 1 \pm 0.5\end{array}$ & $\begin{array}{ll}\mathrm{t}=0.375, & \mathbf{P}<0.8 \\
\mathrm{t}=0.53, & P<0.7 \\
\mathrm{t}=1.00, & P<0.4\end{array}$ \\
\hline $\begin{array}{l}\text { Fibrinogen } \\
(\mathrm{mg} / 100 \mathrm{ml})\end{array}$ & $\begin{array}{l}\text { Europeans } \\
\text { Asians } \\
\text { Africans }\end{array}$ & $\begin{array}{l}253 \pm 97 \\
298 \pm 64 \\
286 \pm 65\end{array}$ & $\begin{array}{l}253 \pm 94 \\
306 \pm 73 \\
305 \pm 80\end{array}$ & $\begin{array}{ll}\mathrm{t}=0.098, & \mathrm{P}<0.95 \\
\mathrm{t}=0.39, & \mathrm{P}<0.8 \\
\mathrm{t}=0.85, & P<0.5\end{array}$ \\
\hline
\end{tabular}

Table II Plasminogen and fibrinogen levels after both types of breakfast in each group
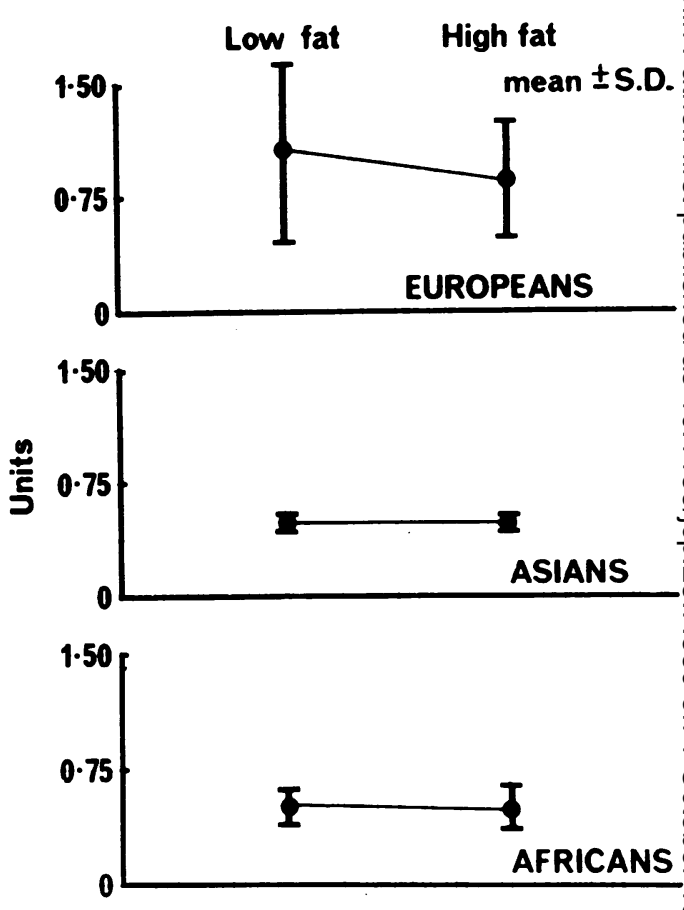

Fig. 2 Urokinase sensitivity expressed in units (mean and standard deviation) after both types of breakfast in each group.

PLASMINOGEN AND FIBRINOGEN LEVELS These results are shown in Table II. In all three groups no significant difference was noted in the levels of plasminogen and fibrinogen after the fatty breakfast as compared with the contro breakfast.

Platelet AGgREgation in CHANDLER's TUBE

The results are listed in Table III. In the EuroN peans the time for platelet aggregation was signi ficantly prolonged by the fat-supplemented meab

\begin{tabular}{|c|c|c|}
\hline \multirow[t]{2}{*}{ Group } & \multicolumn{2}{|l|}{ Breakfast } \\
\hline & Low Fat & High Fat \\
\hline $\begin{array}{l}\text { Europeans } \\
\text { Asians } \\
\text { Africans }\end{array}$ & $\begin{array}{l}521 \pm 87 \\
681 \pm 132 \\
720 \pm 245\end{array}$ & $\begin{array}{l}603 \pm 68 \\
843 \pm 299 \\
642 \pm 253\end{array}$ \\
\hline
\end{tabular}

Table III Time for platelet aggregation (seconds after both types of breakfast in each group 
$(t=4.26, P<0.01)$. This effect was not observed in either the Asian $(t=2 \cdot 11, P>0 \cdot 10)$ or African groups $(t=0 \cdot 46, P>0 \cdot 1)$.

\section{PLATELET COUNT}

These results are shown in Table IV. No significant difference was noted in the platelet counts after the control breakfast as compared with the test breakfast in either of the three groups.

\section{STYPVEN TIME}

These results are shown in Figure 3. In all groups this was significantly reduced after the fatty breakfast as compared with the control. The fall was of similar proportion in all groups $(\mathrm{P}<0.001$ in each case).

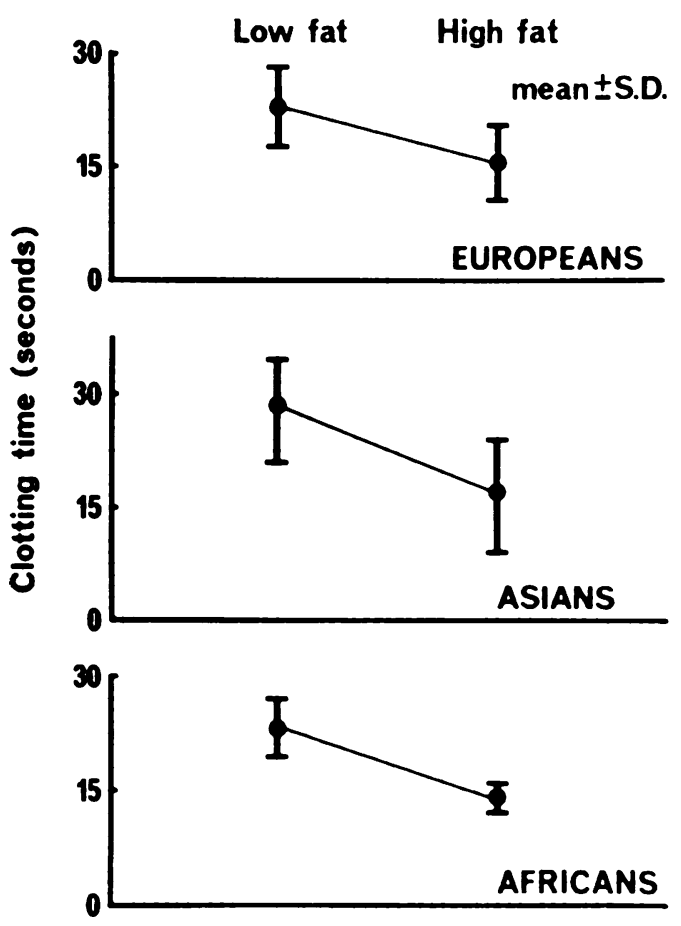

Fig. 3.
BLOOD TRIGLYCERIDE LEVELS

The results are shown in Table V. Significant increases occurred in the levels of triglycerides (Europeans $t=4.43, P<0.005$; Africans $t=\widetilde{O}$ $6.09, \quad \mathrm{P}<0.001$; Asians $\mathrm{t}=5.64, \quad \mathrm{P}<0.001)$ demonstrating adequate absorption of thes? ingested fat.

\section{COMPARISON BETWEEN GROUPS}

Apart from the observation made in each group with regard to the effect of the fatty meal, certain other comparisons were made. In Fig. 4 is shown $\vec{\circ}$ the basal euglobulin clot lysis activity for each $\vec{H}$ group, ie, after the control breakfast. The Euro- $\omega$ peans have the lowest level of activity, thes Africans the highest, and the Asians occupy an intermediate position. The difference in mean

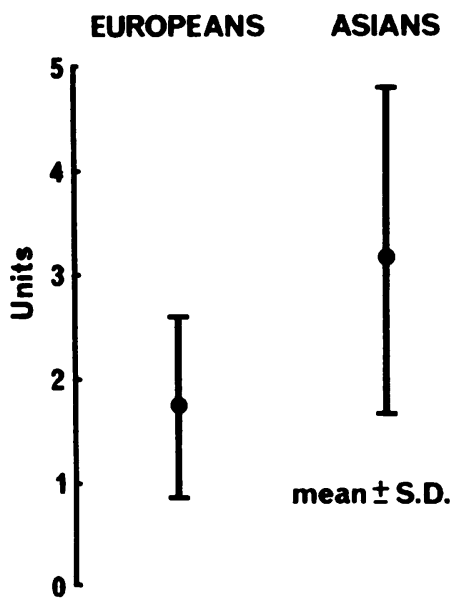

Fig. 4.

Fig. 3 Stypven time in seconds (mean and standard deviation) after both types of breakfast in each group.

Fig. 4 Euglobulin clot lysis activity (mean and standard deviation) for each group after low fat breakfast.

\begin{tabular}{llll}
\hline Group & \multicolumn{2}{l}{ Breakfast } & \multirow{2}{*}{ Significance } \\
\cline { 2 - 3 } & Low Fat & High Fat & \\
\hline Europeans & $219 \cdot 7 \pm 58 \cdot 6$ & $232 \cdot 4 \pm 50 \cdot 2$ & $\mathrm{t}=1 \cdot 18, \mathrm{P}<0.3$ \\
Asians & $184 \pm 136 \cdot 1$ & $187 \pm 26 \cdot 2$ & $\mathrm{t}=0.20, \mathrm{P}<0.9$ \\
Africans & $188 \pm 33.7$ & $190 \pm 24.9$ & $\mathrm{t}=0.04, \mathrm{P}<0.97$
\end{tabular}

Table IV Platelet counts (thousands/mm ${ }^{3}$ ) after both types of breakfast in each group

\begin{tabular}{|c|c|c|}
\hline \multirow[t]{2}{*}{ Group } & \multicolumn{2}{|l|}{ Breakfast } \\
\hline & Low Fat & High Fat \\
\hline $\begin{array}{l}\text { Europeans } \\
\text { Asians } \\
\text { Africans }\end{array}$ & $\begin{array}{r}81 \pm 34 \\
140 \pm 60 \\
84 \pm 27\end{array}$ & $\begin{array}{l}164 \pm 82 \\
421 \pm 183 \\
212 \pm 73\end{array}$ \\
\hline
\end{tabular}

Table V Serum triglyceride levels after both types of breakfast in each group 


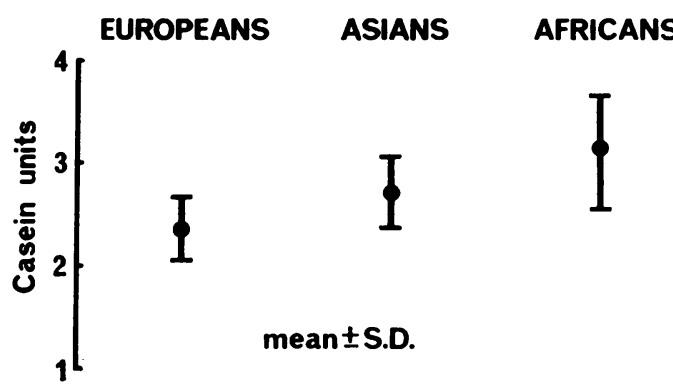

Fig. 5 Plasminogen levels (casein units-mean and standard deviation) for each group after the low fat breakfast.

euglobulin clot lysis activity between Europeans and Africans $(t=7.06, P<0.001)$ or Asians $(t=2.52, P<0.05)$ is significant. The difference, however, between Africans and Asians $(t=$ $2 \cdot 05, P>0.10$ ) is not significant.

The same pattern can again be seen in Fig. 5 where the basal plasminogen levels are plotted. The differences between the Europeans and the Africans $(t=3.71, P<0.005)$ or Asians $(t=$ 2.34, $P<0.05)$ are significant. The difference between the Africans and the Asians, however, is not significant $(t=2 \cdot 02, P>0 \cdot 10)$.

\section{Discussion}

The evidence presented demonstrated that a high fat meal which produced striking hyperlipidaemia in every subject influenced fibrinolytic activity in a different manner in Europeans as compared with Africans and Asians. The fat meal caused a significant depression of euglobulin clot lysis activity and increased resistance of plasma clots to lysis by urokinase in Europeans but was without such influence in Africans and Asians. In all three racial groups plasminogen and fibrinogen levels were unchanged after the fatty meal, suggesting that the changes in lytic activity in the Europeans could not therefore be attributed to change in these levels. The fat load appeared to influence platelet aggregation in the Europeans by prolonging the time taken to aggregation in the Chandler's tube but this effect did not occur in either the Asians or the Africans.

The results show that in Europeans only, of the three ethnic groups studied, hyperlipidaemia both accelerates blood coagulation as measured by the Stypven time and inhibits fibrinolytic activity. If, as has been postulated, persistence of fibrin deposits on the endothelium is important in the genesis of atheroma, the shortening of the Stypven time by increasing the tendency to fibrin formation and the impairment of fibrinolytic activity by interfering with the removal of fibrin might tend to facilitate the development of $\frac{\rho}{\bar{F}}$ atheroma. It is also of interest that the control 0 level of the euglobulin clot lysis activity, ie, after $\stackrel{\mathcal{O}}{\vec{\sigma}}$ a low fat breakfast was substantially different in $\underline{\text {. }}$ each group, the Africans showing much gr eater lytic activity than Europeans or Asians and the $\stackrel{?}{?}$ Asians showing significantly greater activity than $\bar{E}$ Europeans. A similar pattern was also seen in the $\underline{\bar{O}}$ levels of plasminogen after the control breakfast. $\frac{\bar{D}}{\sim}$

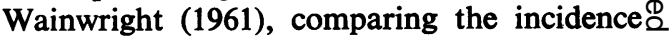
of atherosclerosis in Europeans, Africans, and Asians in Natal, found that the Europeans were most affected, the Africans least so, and that the Asians occupied an intermediate position. The $\vec{\omega}$ pattern of differences in basal euglobulin clot? lysis activity and basal plasminogen levels foundo in the present study in the different racial groups is compatible with the theory that fibrinolytic $-v$ activity may have a role in the genesis of the vary-ir ing incidence of atheroma in these groups. Theo failure of the high fat breakfast to depress윽 fibrinolytic activity in Africans and Asians mayhave some bearing on the observed racial differ-O ences in the incidence of atheroma. Increasedo euglobulin clot lysis activity in Africans and Asians as compared with Europeans has also $-\vec{\oplus}$ been shown by Menon (1967). However, he was unable to show any difference between Europeans. and Asians resident in Britain and he did not report plasminogen levels.

The work presented here in which Europeans, Africans, and Asians from comparable socioeconomic groups were studied suggests that there $\mathbb{Q}$ may be genetic differences between Europeans, $\overrightarrow{\vec{O}}$ Africans, and Asians with respect to the levels of 3 activity of their fibrinolytic enzyme system which? may play a part in determining the differing? incidences of atherosclerosis which have been observed in these three racial groups.

Our thanks are due to Dr B. M. Rifkind who응 performed the lipid assays. Professor S. Alstead $>$ and Professor A. S. Douglas played a major role in establishing laboratory facilities.

Financial assistance was provided by the ${ }^{\text {o }}$ Kenya Ministry of Health, East African Medical $\tilde{O}^{\circ}$ Research Council, Ministry of Overseas Develop- $\omega$ ment, Hoechst (East Africa) Limited, Pfizers Tropical Research Laboratory, Merck, Sharpo and Dohme Laboratories, Pfizer Corporation, and I.C.I. Pharmacuetical Division. Reagents? were provided by A.B. Kabi, Stockholm, Sweden.

\section{References}

Alkjaersig, N., Fletcher, A. P., and Sherry, S. (1959). The mech-O anism of clot dissolution by plasmin. J. clin. Invest., 38 1086-1095.

Dacie, J. V. (1956). Practical Haematology, 2nd ed, Churchills 
Dubber, A. H. C., Rifkind, B., Gale, M., McNicol, G. P., and Douglas, A. S. (1967). The effect of fat feeding on fibrinolysis, Stypven time, and platelet aggregation, J. Atheroscler. Res., 7, 225-235.

Duguid, J. B. (1946). Thrombosis as a factor in the pathogenesis of coronary atherosclerosis. J. Path. Bact., 58, 207-212.

MacLagan, N. F., Billimoria, J. D., and Curtis, C. (1958). Lipaemia and blood coagulation with special reference to the Stypven technique. Lancet, 2, 865-869.

McNicol, G. P., and Douglas, A. S. (1964). Recent Advances in Clinical Pathology, edited by S. C. Dyke, series IV, p. 187. Churchill, London.

McNicol, G. P., Gale, S. B., and Douglas, A. S. (1963). In-vitro and in-vivo studies of a preparation of urokinase. Brit. med. J., 1, 909-915.

Menon, I. S. (1967). Fibrinolytic activity in the blood of Nigerian students after 4 years' residence in the U.K. Lab. Pract., 16, 574-577.

Menon, I. S. (1968). Fibrinolytic activity in the blood of 99 healthy young British, African, and Asian subjects. Lab. Pract., 17, 194-195.
Nilsson, I. M., and Olow, B. (1962). Fibrinolysis induced byㅡㅡㄹ streptokinase in man. Acta chir. scand., 123, 247-266.

Ratnoff, O. D., and Menzie, C. (1951). A new method for the determination of fibrinogen in small samples of plasma? J. Lab. clin. Med., 37, 316-320.

Remmert, L. F., and Cohen, P. P. (1949). Partial purification and $\frac{\mathrm{O}}{-}$ properties of a proteolytic enzyme of human serum. J. biol. Chem., 181, 431-447.

Rokitansky, C. (1852). A Manual of Pathological Anatomy Vol. 4. Sydenham Society, London.

Sherry, S., and Alkjaersig, N. (1957). Studies on the fibrinolytic으 enzyme of human plasma. Thrombos. Diathes. Haemorrh. $\bar{\alpha}$ (Stuttg.), 1, 264-288.

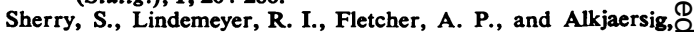
N. (1959). Studies on enhanced fibrinolytic activity man J. clin. Invest., 38, 810-822.

Van Handel, E, and Zilversmit, D. B. (1957). Micromethot forthe direct determination of serum triglycerides. J. Lab. clin. Med., 50, 152-157.

Wainwright, J. (1961). Atheroma in the African (Bantu). incu Natal. Lancet, 1, 366-368. 